\title{
Lessons learned from closure of mine facilities
}

\author{
CL Strachan MWH Americas Inc., USA \\ MM Davis MWH Americas Inc., USA
}

\begin{abstract}
Mine facilities decommissioning, closure, and rehabilitation have been conducted at sites in the Western Hemisphere (in particularly the Western United States) for several decades. This time period has allowed the planning, permitting, closure, and post-closure performance to be evaluated. This paper outlines the primary lessons learned from involvement at a number of sites in various climate and topographical settings. From these examples, the primary closure issues discussed in the paper include: (1) post-closure property control and land use; (2) stakeholder relationships and commitments; (3) residual waste material management; (4) design period and post-closure maintenance; (5) water management (before, during, and after closure), and (6) socio-economic impacts.
\end{abstract}

\section{Introduction}

Mine facilities decommissioning, closure, and rehabilitation (reclamation) have been conducted at sites in the Western United States under varying climatic and topographic conditions. Climates range from arid to wet (experiencing both rain and snow). Site topography ranges from relatively flat areas to steep mountainous conditions. Fortunately, information on rehabilitation performance at sites that were closed several decades ago allows modifications in closure strategy and execution with sites currently facing or undergoing closure. This paper provides an overview of mine facilities closure through lessons learned from projects in the Western United States and other areas of North and Central America.

Mine facilities closure in the United States has evolved from abandoning mines and discharging tailings into watercourses in the late 1800 s and early 1900 s to current requirements to plan and provide financial surety for closure as a requirement for permitting a new mine. Closure requirements depend on individual state regulatory organisation, as well as the land status of the mine site (privately held land or public land). For some states, tailings impoundments are regulated under dam safety rules, while in other states, tailings impoundment regulations are under groundwater or aquifer protection rules.

In Arizona, for example, prescriptive guidelines for mine facilities closure are included in aquifer protection permit requirements (ADEQ 1998). Nevada has similar closure requirements under their groundwater protection program (NDEP 1994). In California, mine facilities closure is regulated by dam safety, water quality, and health services agencies, depending on the mine waste classification (CMA 1992). In Colorado, mine facilities closure is under the jurisdiction of the Office of Mined Land Reclamation, with inactive facilities under the Division of Reclamation Mining Safety, and surface water quality issues under the Colorado Department of Public Health and Environment.

Mines on public lands, such as those administered by the U.S. Forest Service or the U.S. Bureau of Land Management (BLM), must meet Federal land management agency-specific closure guidelines (such as BLM 1992) as well as applicable state regulations.

Abandoned mines have been closed under specific state programs (such as Abandoned Mine Land programs) from grants from the U.S. Department of Interior. Abandoned mines with an uncontrolled release of contaminants through water or air may be remediated under U.S. Environmental Protection Agency (EPA) control under the Comprehensive Environmental Response, Compensation, and Liability Act (CERCLA) program. 
Uranium tailings impoundments are reclaimed under the Uranium Mill Tailings Radiation Control Act (UMTRCA). Older sites that were operated for the former U.S. Atomic Energy Commission are reclaimed under the direction of the U.S. Department of Energy (DOE), with closure plan approval by the U.S. Nuclear Regulatory Commission (NRC). Sites operated for industrial use are reclaimed by the land owners or private companies responsible for the site, with closure plan approval by the NRC. The reclaimed sites are eventually transferred to the Office of Legacy Management of the DOE (described in Strachan et al. 2009). The closure planning and design of these sites is conducted according to technical guidelines for uranium mill tailings impoundments published by the NRC (Nelson et al. 1983, 1986; Johnson 2002). These guidelines are based on long-term performance conditions for isolation of tailings over an effective design life of 200 to 1,000 years.

Canadian mine closure requirements are similar to U.S. requirements, with mine closure plans and estimated closure costs included as part of mine permitting. Closure plan regulations and requirements are administered by each province, but with common closure elements (McKenna et al. 2013).

The primary closure issues from our experience (that may have application in Australia) are organised in the following sections: (1) post-closure property control and land use, (2) stakeholder relationships and commitments, (3) residual waste material management, (4) design period and post-closure maintenance, (5) water management (before, during, and after closure), and (6) socio-economic impacts.

\section{$2 \quad$ Property control and land use}

Uranium tailings impoundment closure under the UMTRCA program provides a clear path for post-closure property control and land use. After closure is completed and following a five-year post-closure monitoring period, closure is reviewed by the NRC for compliance with performance standards (NRC 2005). If performance standards and property title conditions are met, the tailings impoundment and surrounding affected area is transferred to the DOE for long-term care and maintenance, as well as institutional control (restricting access by the general public).

Mine facilities on public lands have a similar path, where the site may be returned to the U.S. Bureau of Land Management or U.S. Forest Service when closure or reclamation objectives are met. Cumbers et al. (2014) provide a case history of an underground mine site on U.S. Forest Service land that was reclaimed to meet wildlife habitat and grazing land-use conditions. Closure included consolidation of mined materials and debris into a single, covered repository.

Mine facilities on private land have a different property control path. Land that meets closure standards and has no residual liability may be sold. Tailings impoundments and other mine facilities are typically retained by the owner for ongoing monitoring and maintenance due to the potential liability of misuse by a future owner. In some cases, closed mine facilities may also pose a hazard to neighbouring communities, as well as the potential to be misused by people not familiar with the facility. At a mine site in Central America, a concrete-lined spillway from a tailings impoundment was designed for long-term, post-closure performance. Due to neighbouring grazing and small-scale farming activity, access restrictions were incorporated into the spillway design to prevent access into the spillway, and also to prevent tampering with the spillway controls for water storage and water release (Strachan et al. 2014a, 2014b). Despite this, the owner will have to maintain control of the property for some time into the future.

\section{Relationships and commitments with stakeholders}

Relationships with stakeholders and nearby communities may be documented in permits and closure plans. Due to the long duration of typical mine facility operations, neighbours may change before mine closure, and expect a different post-closure land use than was anticipated or approved at mine start-up. Clear documentation during permitting and operations of post-closure land use, expectations of stakeholders, and closure commitments is essential.

In Colorado, many mining districts were developed in the late 1800s, and mining-related employment was the primary source of income. Towns such as Aspen, Crested Butte, and Telluride were located and 
developed as mining towns. With the transition to skiing-related tourism in each of these towns, demographics have changed along with expectations for closure of the residual mine facilities.

The Canyon City uranium mill in southern Colorado was developed in the 1960s outside of the town of Canyon City. Since then, the neighbouring property has been developed into home sites on large parcels of land. The formerly isolated location of the mill has become nearly surrounded by residents who do not want an industrial facility (such as a mill) within view of their homes. Other areas of the Western United States have experienced a transition from a neighbouring community where the majority of residents sought employment (such as mining jobs) to a neighbouring community where the majority of residents are retired and do not want mining. These demographic changes affect mine facilities' closure expectations and commitments.

\section{$4 \quad$ Residual waste material management}

For many mill site closures, non-salvageable equipment and structural materials are demolished and buried in the tailings impoundment or in other approved onsite locations. Ideally, demolished debris is buried in the tailings impoundment along with contaminated soils and other waste materials before the final cover is placed.

At the Panna Maria uranium mill site in South Texas, additional contaminated soils were encountered near the end of tailings impoundment cover placement. Rather than modify the existing cover system, mounded areas were developed along the perimeter of the tailings impoundment to provide capacity for the additional contaminated soil while maintaining desired runoff controls (Strachan \& Raabe 1998, 2008).

At the Ray Point uranium mill site in South Texas, tailings impoundment closure and covering was conducted in the 1980s (Miller et al. 1989). Prior to tailings impoundment closure, demolition and contaminated site soil clean up were conducted, with the debris and soils placed in the tailings impoundment. After 2001, final radiological surveying of the site was conducted using survey equipment that was more accurate than the equipment available in the 1980s. With the new equipment, additional areas of soil clean up were identified. A small repository for this material was designed, permitted, and constructed adjacent to the reclaimed tailings impoundment. The repository surface was sloped to be consistent with overall site drainage plans.

At other sites, ongoing water treatment or evaporation produce sludges or evaporites that require disposal after the tailings impoundment or other onsite repositories have been closed or covered. The tailings impoundment at the Grouse Creek Mine in Idaho was closed over a period of years. This schedule allowed treatment and of discharge process water and affected storm water, and allow the tailings to settle to facilitate cover construction. During this period, water treatment plant sludge was discharged into the tailings impoundment. The remaining tailings cover was completed in 2012 (Moye 2014). While water treatment rates have significantly decreased, ongoing water treatment of residual water requires a repository for water treatment plant sludge.

The geochemical behaviour of tailings and other mine waste materials dictates how these materials are managed after closure. The general strategy is to minimise infiltration of meteoric water into the material, and for materials that have oxidizing components, minimize the oxygen flux into or through the material. Strachan et al. (1998) describe the characterization of tailings at a site in Colorado where there was a potential for post-closure acid drainage due to the presence of sulphide minerals. However, oxygen flux measurements and evaluation of downstream water quality demonstrated that this potential was minimized due to the low permeability and degree of saturation of the tailings. While maintaining saturated conditions has been used for prevention of sulphide mineral oxidation in tailings and other mine waste materials (particularly in wet environments), the long-term stability of a facility with a water cover requires a level of monitoring and maintenance for a water-storage facility.

\section{$5 \quad$ Design period and post-closure maintenance}

In the United States, design criteria for closure are based on the selected design periods and potential consequence of failure. In Idaho, requirements for closure include providing a stable, maintenance-free condition, with diversion structures or channels to accommodate runoff (Idaho Administrative Procedures 
Act, Section 37.03.05.045). In Arizona, the prescriptive design storm recurrence interval is the 100-year event (one per cent probability of exceedance in one year), but with latitude (based on potential consequence of failure) to incorporate design storm events from the 25-year recurrence interval to the probable maximum precipitation (PMP), depending on potential downstream risk from failure. ICOLD design event criteria for water storage and tailings dams range from the 50-year recurrence interval flood event to the probable maximum flood, depending on impoundment size and potential downstream consequence of failure (ICOLD 1989, 1992).

For closed mine facilities with minimal active maintenance, the anticipated period of performance is assessed to select the design storm event for channel sizing and surface erosion protection selection, with consideration for the consequence of failure. The effect on period of performance on probability of failure is illustrated in Table 1, from probability calculations summarised in Vick (1990) and ADEQ (1998).

Table 1 Probability of Failure for Various Periods of Performance

\begin{tabular}{cccc}
\hline $\begin{array}{c}\text { Period of } \\
\text { performance } \\
\text { (years) }\end{array}$ & $\begin{array}{c}\text { Recurrence } \\
\text { interval } \\
\text { (years) }\end{array}$ & $\begin{array}{c}\text { Probability } \\
\text { of failure in } \\
\text { one year }\end{array}$ & $\begin{array}{c}\text { Probability of failure } \\
\text { during period of } \\
\text { performance }\end{array}$ \\
\hline 1 & 100 & $1.0 \%$ & $1.0 \%$ \\
\hline 10 & 100 & $1.0 \%$ & $10 \%$ \\
\hline 50 & 100 & $1.0 \%$ & $39 \%$ \\
\hline 100 & 100 & $1.0 \%$ & $63 \%$ \\
\hline 100 & 1,000 & $0.1 \%$ & $10 \%$ \\
\hline
\end{tabular}

For the 100-year recurrence interval event, the probability of failure in one year is one per cent. For the same recurrence interval, the probability of failure over 10 years is 10 per cent, over 50 years is 39 per cent, and over 100 years is 63 per cent. For example, a diversion channel designed for a 100 -year recurrence interval storm has a 10 per cent probability of being overtopped in 10 years and a 63 per cent probability (greater than a 50/50 chance) of being overtopped in 100 years. If the channel is designed for the 1,000-year recurrence interval, the probability of being overtopped in 100 years is reduced to 10 per cent. Reclaimed mine facilities with drainage channels or soil covers that will remain in place for decades (with minimal maintenance) require design for more extreme storm events.

For uranium tailings impoundment reclamation, the performance period for design is 1,000 years, or at least 200 years if the 1,000-year period cannot be justified (Appendix A, 10 CFR 40). For this long performance period, the PMP is the recommended design storm event (Nelson et al. 1983). In the United States and Australia, the PMP is a deterministic meteorological calculation, and not based on a precipitation record (Strachan et al. 2015). In the United States, these calculations are published in various hydrometeorological reports (such as NOAA 1980, 1982). Elsewhere, the PMP estimate is based primarily on a statistical evaluation of local or regional precipitation records (WMO 2009).

For uranium tailings impoundment reclamation in the United States, designs do not include man-made materials such as geomembranes or concrete (Appendix A, 10 CFR 40), since these materials have not been in place or determined to be effective over the performance period of 200 to 1,000 years. Durable riprap and other natural materials with smooth, gently-sloping surfaces are used to provide surface stability under PMP design conditions with minimal maintenance.

For reclamation of non-uranium mine facilities in steep topographical areas, concrete may be required for grouted riprap or other channel lining applications. Due to the performance life of concrete relative to decades of post-closure period, some maintenance or repair at these facilities may be necessary by the entity responsible for the site after closure. 


\section{Water management}

One of the key aspects of actual closure work is management of residual process water and storm water. At the Conquista uranium mill site in South Texas, residual process water was evaporated in cells constructed within the tailings impoundment. This process evaporated approximately 160 million gallons $\left(606,000 \mathrm{~m}^{3}\right)$ of water from 1985 through 1991. Concurrent with evaporation, the cover system was extended to allow runoff from covered surfaces to be discharged as stormwater. In December 1991, less than 2 million gallons $\left(7,000 \mathrm{~m}^{3}\right)$ of process water remained within the evaporation cells inside tailings impoundment when the site crew left the site for the Christmas holiday. Within the next three months, the site received approximately 25 inches $(635 \mathrm{~mm})$ of precipitation, adding approximately 40 million gallons $\left(150,000 \mathrm{~m}^{3}\right)$ to the process water inventory. Evaporation of this additional water delayed the closure construction schedule by one year (Strachan \& Olenick 1994).

At other sites, evaporation of residual process water becomes the critical path for closure, and this ponded water impedes remaining cover construction. Either the closure schedule is extended to allow evaporation to be completed, or temporary evaporation ponds are constructed to store and evaporate residual process water while allowing tailings cover construction to proceed (Strachan \& Raabe 1998).

With closure activities, areas of exposed slopes and cover surfaces are susceptible to erosion and runoff before permanent surface protection is placed or vegetation is established. In cases in the United States where the probability of runoff from these exposed surfaces is significant, temporary erosion control features (erosion control mats or netting, silt fences, detention ponds) may be necessary to reduce suspended solids in stormwater that is discharged off of the site.

\section{$7 \quad$ Socio-economic impacts}

Mine facilities closure also has an effect on the socio-economics of the mine area. From our experience with mine facilities closure in rural areas of the Western United States, mine or mill closure resulted in a change from employment of several hundred people (with job training and relatively high wages) to a care and maintenance staff of less than 10 people after closure. That has a significant local impact on the affected employees, supporting businesses, and sales tax revenues.

International objectives for mine facilities closure (IFC 2007) reflect this socio-economic impact, as listed below.

A mine closure plan that incorporates both physical rehabilitation and socio-economic considerations should be an integral part of the project life cycle and should be designed so that:

- Future public health and safety are not compromised;

- The after-use of the site is beneficial and sustainable to the affected communities in the long term;

- Adverse socio-economic impacts are minimized and socio-economic benefits are maximized.

Meeting these objectives at operating mine facilities would involve relocation of staff to other mine sites or training of staff for other forms of employment.

\section{Conclusion}

More specific recommendations for closure planning that can facilitate more cost-efficient and successful reclamation are listed below.

- Establish post-closure site ownership, land use, long-term maintenance and control. Closure and reclamation planning should be consistent with post-closure land use, site control, and long-term maintenance.

- Avoid post-closure water treatment where possible.

- Plan during operations to identify potential materials to be used in closure (cover soils, revegetation materials, drainage materials, riprap) that are durable and non-mineralised. 
- Plan to limit material re-handling during closure.

- Assess closure costs realistically, since actual closure costs at many sites are higher than initially estimated, due to increases in fuel costs and labour rates, availability of contractors and equipment at the time of closure, and costs of water treatment to meet discharge water quality standards after closure.

\section{References}

ADEQ (Arizona Department of Environmental Quality) 1998, Arizona BADCT Guidance Manual, Aquifer Protection Program, Arizona Department of Environmental Quality, Water Quality Division.

BLM (U.S. Department of Interior, Bureau of Land Management) 1992, 'Solid Minerals Reclamation Handbook', BLM Manual Handbook H-3042-1, April.

CMA (California Mining Association) 1992, Mine Waste Management, IPG Hutchison and RD Ellison (eds), Lewis Publishers.

Cumbers, JM, Dornfest, EM \& Dwyer, SF 2014, 'Case Study: Uranium mine site removal action and ET cover construction', Tailings and Mine Waste '14, University of British Columbia (publishers), Keystone, Colorado, 5-8 October 2014, pp. 553-564.

ICOLD (International Commission on Large Dams) 1989, 'Tailings Dam Safety Guidelines', ICOLD Bulletin 74, Paris.

ICOLD (International Commission on Large Dams) 1992, 'Selection of Design Flood, Current Methods', ICOLD Bulletin 82, Paris.

IFC (International Finance Corporation) 2007, Environmental, Health, and Safety Guidelines for Mining, World Bank Group, December.

Johnson, TL 2002, 'Design of Erosion Protection for Long-Term Stabilization', NUREG-1623, U.S. Nuclear Regulatory Commission, September.

McKenna, G, An, R, Scordo, E \& McGreevy, J 2013, 'Toward effective closure planning: From progressive reclamation to sustainable mining', Tailings and Mine Waste '13, University of Alberta (publishers), Banff, Alberta, 3-6 November 2013, pp. 615-626.

Miller, LL, Estey, HP \& Strachan, CL 1989, 'Reclamation of Exxon Ray Point Tailings Basin', Journal of Energy Engineering, ASCE, Vol. 115, No. 3, December 1989, pp. 120-131.

Moye, F 2014, 'An overview of the Grouse Creek Mine tailings impoundment closure', Tailings and Mine Waste '14, University of British Columbia (publishers), Keystone, Colorado, 5-8 October 2014, pp. 541-552.

Nelson, JD, Abt, SR, Volpe, RL, van Zyl, D, Winkle, NE and Staub, WP 1986, 'Methodologies for Evaluating Long-Term Stabilization Designs of Uranium Mill Tailings Impoundments', NUREG/CR-4620, U.S. Nuclear Regulatory Commission, June.

Nelson, JD, Volpe, RL, Wardwell, RE, Schumm, SA and Staub, WP 1983, 'Design Considerations for Long-Term Stabilization of Uranium Mill Tailings Impoundments', NUREG/CR-3397, U.S. Nuclear Regulatory Commission, October.

NDEP (Nevada Division of Environmental Protection) 1994, Preparation Requirements and Guidelines for Permanent Closure Plans and Final Closure Reports, Bureau of Mining Regulation and Reclamation, September.

NOAA (National Oceanic and Atmospheric Administration and U.S. Nuclear Regulatory Commission) 1980, 'Seasonal Variation of 10-Square-Mile Probable Maximum Precipitation Estimates - Unites States East of the 105th Meridian', NOAA Hydrometeorological Report No. 53, Silver Spring, MD.

NOAA (National Oceanic and Atmospheric Administration and U.S. Army Corps of Engineers) 1982, 'Application of Probable Maximum Precipitation Estimates - Unites States East of the 105th Meridian', NOAA Hydrometeorological Report No. 52, Washington D.C.

NRC (U.S. Nuclear Regulatory Commission) 2005, Code of Federal Regulations (CFR), Section 10 Part 40, Appendix A.

Strachan, CL \& Olenick, C 1994, 'Design and Construction of the Closure Plan for the Conquista Uranium Mill Tailings Impoundment', Proceedings of the First International Congress on Environmental Geotechnics, 11-15 July 1994, Edmonton, Alberta, Canada, BiTech Publishers.

Strachan, C \& Raabe, K 1998, 'Reclamation of the Panna Maria Tailings Impoundment: A Case History', Tailings and Mine Waste '98, A.A. Balkema, Fort Collins, Colorado, January 26-28, pp. 825-834.

Strachan, C \& Raabe, K 2008, 'Reclamation of the Panna Maria uranium mill site and tailings impoundment: A 2008 update', Tailings and Mine Waste '08, CRC Press, Vail, Colorado, 20-22 October 2008, pp. 381-391.

Strachan, CL, Aparicio, MA \& Bernedo-Sanchez, CE 2014a, 'Closure Spillway Design for a Tailings Storage Facility in Central America', Proceedings of the 4th International Congress on Water Management in Mining, Viña del Mar, Chile, 28-30 May 2014.

Strachan, CL, Aparicio, MA, Bernedo-Sanchez, CE \& Seda, JH 2014b, 'Water management planning for a tailings storage facility in Central America', Tailings and Mine Waste '14, University of British Columbia (publishers), Keystone, Colorado, 5-8 October 2014, pp. 183-194.

Strachan, CL, Jacobs, M \& Bernedo-Sanchez, CE 2015, 'Engineering Judgment in Design Storm Event Selection for Projects in Extreme Environments', Mine Water Solutions in Extreme Environments 2015, Vancouver BC, 12-15 April 2015, InfoMine, pp. 89-100.

Strachan, C, Smith, G \& Caldwell, J 2009, 'Uranium mill tailings impoundment closure: a retrospective', Tailings and Mine Waste '09, University of Alberta Geotechnical Center, Banff, Alberta, 1-4 November 2009, pp. 15-20.

Strachan, C, Kelley T, Keith D \& Cox A 1998, 'Geochemical and Geotechnical Evaluation of the Bulldog Mine Tailings Impoundment', Tailings and Mine '98, A.A. Balkema, Fort Collins, Colorado, January 26-28, pp. 539-548.

Vick, SG 1990, Planning, Design, and Analysis of Tailings Dams, BiTech Publishers, Vancouver.

WMO (World Meteorological Organization) 2009, 'Manual on Estimation of Probable Maximum Precipitation (PMP)', WMO-No. 1045, Geneva. 